\title{
Activity of Metformin in Selected Malignan Tumours in Women
}

\author{
Janina Markowska* \\ Department of Oncology, Karol Marcinkowski Medical University in Poznan, Poland
}

Submission: February 09, 2018; Published: February 22, 2018

*Corresponding author: Janina Markowska, Department of Oncology, Karol Marcinkowski Medical University in Poznan, Poland,

Email: janina.markowska@oncology.am.poznan.pl

\begin{abstract}
Acanthosisnigricans is a fairlycommon skin pigmentationdisorder in obesepeople. This lesi on may be a sign of a moreserious health problem such as metabolic syndrome and some of themalignancy. Over the past several decades, while obesity and metabolic syndrome were a growing health problem across the developed countries, we need to be more cautious and alert about this lesions in routine clinical practice at internal medicine clinics. This case highlights the importance of AN on thelipcorners where AN is rarelylocated.
\end{abstract}

Keywords : Unusual presentation; Acanthosis Nigricans; Obesity

\section{Introduction}

Obesity, type 2 diabetes and malignant tumours are a major global health problem of the 21st century. Metformin, widely used in diabetics and patients with malignant tumours, reduces respective morbidity and mortality due to these diseases. This applies equally well to cancers of the breast, ovary and endometrium. One of the mechanisms of metformin action involves the activation of LKß1/AMPK pathway and inhibition of the mTOR pathway. Another involves the inhibition of cancer stem cells.

Obesity is a global health problem in the 21st century. According to WHO, in 2014, 2.1 billion people over the age of 21 were classed as overweight or obese (BMI $\geq 25$ and $\mathrm{BMI} \geq 30$, respectively). Obesity is linked to an increased incidence of type 2 diabetes, the most widespread disease of contemporary civilization. Obesity and type 2 diabetes are associated with a growing incidence of malignant tumours of various locations, including breast cancer, ovarian cancer and endometrial cancer [1-6].

For more than 50 years metformin, the biguanide drug originating from Medical galega has been applied in the treatment of type 2 diabetes. Metformin reduces morbidity and mortality linked to various tumours (oesophageal cancer, colorectal cancer, cancers of the liver and pancreas), as well as malignant tumours in women. No such an effect was observed when diabetes was treated with insulin or sulphonylurea derivatives.
Meta-analysis of electronic data bases, including over 65 thousand patients with type 2 diabetes and malignant tumours, demonstrated that the use of metformin reduced morbidity by $31 \%$ and mortality by $34 \%$ as compared to treatment with antidiabetics [7-11]. Obesity and diabetes represent documented risk factors in the development of breast cancer in peri- and post-menopausal women. Studies conducted in women with type 2 diabetes demonstrated a protective effect of metformin against the development of breast cancer. In women treated with metformin, a higher frequency of cells positive for progesterone receptors (PgR) was found. A reduced frequency of triple-negative cancers, tumours characterised by high aggressiveness and poor prognosis, was also noted. It was found that metformin, in addition to neoadjuvant chemotherapy significantly elevated the proportion of complete pathological responses. The antineoplastic effect of metformin may provide a supplementary treatment to conventional therapeutic option [11-14].

\section{Ovarian cancer}

The application of metformin in patients with type 2 diabetes was demonstrated to significantly reduce the risk of ovarian cancer development. Observational results demonstrated a significant increase in progression free survival (PFS) and overall survival (OS) in women treated with the conventional therapy of cytostatic drugs together with metformin due to diabetes. Metformin increased the percentage of 5-year survival (67\%) in 
patients treated due to ovarian cancer in comparison to women without diabetes who underwent chemotherapy only [15-18].

\section{Endometrial cancer}

Numerous studies demonstrated the link between the development of endometrial cancer, diabetes and obesity. Meta analysis of electronic data bases, including 760,000 patients suffering from type 2 diabetes, demonstrated reduced morbidity resulting from endometrial cancer by $13 \%$ in women treated with metformin. This statistically significant reduction was not seen in patients with type 2 diabetes treated with other antidiabetics. It was found that metformin reduced mortality in women with endometrial cancer, including those with additional diseases [19-22].

The mechanism of metformin action is complex and includes numerous distinct interaction pathways, such as:

A. Activation of LK $\beta 1 /$ AMPK pathway: the activation of AMPK pathway by metformin develops with the mediation of LK $\beta 1 \mathrm{~K}$ liver kinase resulting in the inhibition of $\mathrm{mTOR}$ pathway

B. Direct inhibition of mTOR, independent of AMPK and LK $\beta 1$

C. Reduced concentration of circulating insulin, inducing cell divisions and affecting the P13K pathway, linked to antiapoptotic signalling

D. Promotion of autophagy

E. Activation of immune system

F. A reduction of cyclin $\mathrm{D}_{1}$ activity, a decrease in antiapoptotic Bcl-2 and Bcl-x proteins and an increase in concentration of pro-apoptotic Bax

G. Inhibition of cancer stem cell (CSC) activity, linked to a resistance to chemotherapy, radiotherapy, to progression of the disease and metastases.

Apart from the antidiabetic value of metformin, the additional anticancer activity of this drug provides a reason for further clinical studies [23-30].

\section{References}

1. Budnik A, Henneberg M (2017) Worldwide increase of obesity is related to the reduced opportunity for natural selection. PLoS One 12(1): e0170098.

2. You W, Henneberg M (2017) Cancer incidence increasing globally: The role of relaxed natural selection. Evol Appl 11(2): 140-152.

3. Buono G, Crispo A, Giuliano M, De Angelis C, Schettini F, et al. (2017) Combined effect of obesity and diabetes on early breast cancer outcome: a prospective observational study. Oncotarget 8(70): 115709-115717.

4. Johnson JA, Bowker SL (2011) Intensive glycaemic control and cancer risk in type 2 diabetes: a meta-analysis of major trials. Diabetologia 54(1): 25-31.
5. Anderson AS, Key TJ, Norat T, Scoccianti C, Cecchini M, et al. (2015) European Code against Cancer 4th Edition: Obesity, body fatness and cancer. Cancer Epidemiol 39 Suppl 1: S34-S45.

6. Mazzarella L (2015) Why does obesity promote cancer? Epidemiology, biology, and open questions. Ecancermedicalscience 9: 554.

7. Daugan M, Dufaÿ Wojcicki A, d'Hayer B, Boudy V (2016) Metformin: An anti-diabetic drug to fight cancer. Pharmacol Res. 113(Pt A): 675-685.

8. Zhou XL, Xue WH, Ding XF, Li LF, Dou MM, et al. (2017) Association between metformin and the risk of gastric cancer in patients with type 2 diabetes mellitus: a meta-analysis of cohort studies. Oncotarget 8(33): 55622-55631.

9. Zhang P, Li H, Tan X, Chen L, Wang S (2013) Association of metformin use with cancer incidence and mortality: a meta-analysis. Cancer Epidemiol 37(3): 207-218.

10. Bowker SL, Majumdar SR, Veugelers P, Johnson JA (2006) Increased cancer-related mortality for patients with type 2 diabetes who use sulfonylureas or insulin. Diabetes Care 29(2): 254-258.

11. Landman GW, Kleefstra N, van Hateren KJ, Groenier KH, Gans RO, et al. (2010) Metformin associated with lower cancer mortality in type 2 diabetes: ZODIAC-16. Diabetes Care 33(2): 322-326.

12. Thor A, Anderson SM (2011) Clinical studies of metformin action in breast cancer. Am J Clin Oncol Educational book, pp. 46-49.

13. Jiralerspong S, Palla SL, Giordano SH, Meric Bernstam F, Liedtke C, et al. (2009) Metformin and pathologic complete responses to neoadjuvant chemotherapy in diabetic patients with breast cancer. J Clin Oncol 27(20): 3297-3302.

14. Garcia A, Tisman G (2010) Metformin, B(12), and enhanced breast cancer response to chemotherapy. J Clin Oncol 28(2): e19.

15. Bodmer M, Becker C, Meier C, Jick SS, Meier CR (2011) Use of metformin and the risk of ovarian cancer: a case-control analysis. Gynecol Oncol 123(2): 200-204.

16. Dilokthornsakul P, Chaiyakunapruk N, Termrungruanglert W, Pratoomsoot C, Saokaew S, et al. (2013) The effects of metformin on ovarian cancer: a systematic review. Int J Gynecol Cancer 23(9): 15441551.

17. Wang SB, Lei KJ, Liu JP, Jia YM (2017) Continuous use of metformin can improve survival in type 2 diabetic patients with ovarian cancer: A retrospective study. Medicine (Baltimore) 96(29): e7605.

18. Kumar S, Meuter A, Thapa P, Langstraat C, Giri S, et al. (2013) Metformin intake is associated with better survival in ovarian cancer: a case-control study. Cancer 119(3): 555-562.

19. Romero IL, McCormick A, McEwen KA, Park S, Karrison T, et al. (2012) Relationship of type II diabetes and metformin use to ovarian cancer progression, survival, and chemosensitivity. Obstet Gynecol 119(1): 61-67.

20. Becker C, Jick SS, Meier CR, Bodmer M (2013) Metformin and the risk of endometrial cancer: a case-control analysis. Gynecol Oncol 129(3): 565-569.

21. Seebacher V, Bergmeister B, Grimm CH, Koelbl H, Reinthaller A, et al. (2016) The prognostic role of metformin in patients with endometrial cancer: a retrospective study. Eur J Obstet Gynecol Reprod Biol 203: 291-296.

22. Soliman PT, Zhang Q, Broaddus RR, Westin SN, Iglesias D, et al. (2016) Prospective evaluation of the molecular effects of metformin on the endometrium in women with newly diagnosed endometrial cancer: A window of opportunity study. Gynecol Oncol 143(3): 466-471.

23. Steinberg GR, Kemp BE (2009) AMPK in health and disease. Physiol Rev 89(3): 1025-1078. 


\section{Current Research in Diabetes \& Obesity Journal}

24. Hardie D (2007) AMP-activated/SNF1 protein kinases: conserved guardians of cellular energy. Nat Rev Mol Cell Biol. 8(10): 774-785.

25. Dowling RJ, Zakikhani M, Fantus IG, Pollak M, Sonenberg N (2007) Metformin inhibits mammalian target of rapamycin-dependent translation initiation in breast cancer cells. Cancer Res 67(22): 10804108012.

26. Kalender A, Selvaraj A, Kim SY, Gulati P, Brûlé S, et al. (2010) Metformin, independent of AMPK, inhibits mTORC1 in a rag GTPase-dependent manner. Cell Metab 11(5): 390-401.

27. Dowling RJ, Goodwin PJ, Stambolic V (2011) Understanding the benefit of metformin use in cancer treatment. BMC Med 9: 33.
28. Gwak H, Kim Y, An H, Dhanasekaran DN, Song YS (2017) Metformin induces degradation of cyclin D1 via AMPK/GSK3 $\beta$ axis in ovarian cancer. Mol Carcinog 56(2): 349-358.

29. Fu YL, Zhang QH, Wang XW, He H (2017) Antidiabetic drug metformin mitigates ovarian cancer SKOV3 cell growth by triggering G2/M cell cycle arrest and inhibition of m-TOR/PI3K/Akt signaling pathway. Eur Rev Med Pharmacol Sci 21(5): 1169-1175.

30. Hirsch HA, Iliopoulos D, Tsichlis PN, Struhl K (2009) Metformin selectively targets cancer stem cells, and acts together with chemotherapy to block tumor growth and prolong remission. Cancer Res 69(19): 7507-7511.

Your next submission with Juniper Publishers will reach you the below assets

- Quality Editorial service

- Swift Peer Review

- Reprints availability

- E-prints Service

- Manuscript Podcast for convenient understanding

- Global attainment for your research

- Manuscript accessibility in different formats

( Pdf, E-pub, Full Text, Audio)

- Unceasing customer service

Track the below URL for one-step submission https://juniperpublishers.com/online-submission.php 